\title{
Copyright
}

by

Melissa Ann Smith

2011 
The Report Committee for Melissa Ann Smith

Certifies that this is the approved version of the following report:

\section{When Fairy Godmothers Are Men: Dickens's Gendered Use of Fairy Tales as a Form of Narrative Control in Bleak House}

\section{APPROVED BY \\ SUPERVISING COMMITTEE:}

Supervisor:

Carol H. MacKay

Linda Ferreira-Buckley 


\title{
When Fairy Godmothers Are Men: Dickens's Gendered Use of Fairy Tales as a Form of Narrative Control in Bleak House
}

by

\section{Melissa Ann Smith, B.A.}

\author{
Report \\ Presented to the Faculty of the Graduate School of \\ The University of Texas at Austin \\ in Partial Fulfillment \\ of the Requirements \\ for the Degree of \\ Master of Arts
}

The University of Texas at Austin

May 2011 


\section{Dedication}

To Edwin Owen Graham (1931-1995) 


\section{Acknowledgements}

Many thanks are due to my supervisor, Carol MacKay, whose intellectual generosity and expertise guided this project to completion. This paper began as a seminar paper for her class on the Victorian novel. Thanks also goes to my reader, Linda FerreiraBuckley, whose clear thinking helped me to articulate my ideas more distinctly and whose warm enthusiasm was welcome and well-timed.

Michael Quatro, fellow classmate, commiserated with me throughout the semester and read the final draft of this paper, despite being busy with his own. I would also like to acknowledge Celeste Hutton and Vernette Chance, whose teaching extended beyond the classroom and whose friendship and support have continued to nurture me as a scholar and lover of literature. 


\begin{abstract}
When Fairy Godmothers Are Men: Dickens's Gendered Use of Fairy Tales as a Form of Narrative Control in Bleak House
\end{abstract}

\author{
Melissa Ann Smith, M.A. \\ The University of Texas at Austin, 2011
}

Supervisor: Carol H. MacKay

This paper explores how Charles Dickens's use of a female narrator in Bleak House (1853) fundamentally problematizes and undermines his use of the fairy tale's cultural cachet, motifs, and characters to prop up and project his fantasies of the feminine ideal. More specifically, it examines the effects of the thematic presence of several taletypes and stock fairy tale figures on Dickens's ability to prescribe ideal feminine behaviors, such as incuriosity and selfless obedience, to both his characters and his female audience. Because Esther's ability to write and her interest in either discovering or constructing her own identity establish her as competitor to the males who attempt to script her life, Dickens tries to control and circumscribe her ability to know and act through her own and other characters' resemblance to traditional fairy tale character types, especially Bluebeard and Griselda. Esther's narrative, however, betrays these unnatural delimitations in telltale interruptions and denials as Dickens attempts to circumvent the constraints he has placed on her voice. Esther's narrative therefore resists but imperfectly overcomes the Victorian male author's scripting of femininity. 


\section{Table of Contents}

I. Introduction .....................................................................................

II. When Fairy Godmothers Are Men ...........................................................6

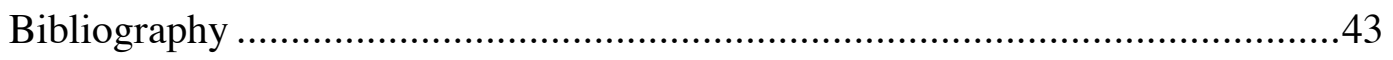

Vita 


\section{Introduction}

Charles Dickens's literary debt to the fairy tale has been of perennial interest to scholars. It has become almost commonplace to detail the author's early and enraptured encounters with Arabian Nights and other fantasy literature (see, for instance, Zipes 89). Michael Kotzin, the first scholar to produce a book-length study of Dickens's relationship to the fairy tale, did so during a wave of new interest in the subject that had been gathering strength throughout the 1950s and '60s (Kotzin 1-2). Kotzin's Dickens and the Fairy Tale (1972) primarily details the cultural heritage of the fairy tale in England, moving towards a collection of instances of Dickens's use of fairy tales in his work. Although Kotzin leaves little room in his study to analyze the thematic import of these tales, he nevertheless sets the stage for further work by pointing out that fairy tale elements are more apparent and frequent in Dickens's later works (74).

Harry Stone expanded on this observation several years later in Dickens and the Invisible World: Fairy Tales, Fantasy, and Novel-Making (1979). One of the first critics to broadly analyze the effect of Dickens's fairy tale tutelage on his most canonical works, Stone argues that Dickens's "writings are profoundly shaped by that early reading and imagining, a shaping that has the fairy tale as its matrix" (3). Stone points out two specific ways fairy tales gained ascendancy in Dickens's mind as sources of humanizing, even redemptive power (56). First, Dickens found escape from his deadening experience in the bottle-blacking factory in fairy tales $(56 ; 60)$; second, he derived a sense of power and garnered recognition by telling stories, at which he was particularly adept (48). With this childhood inspiration in the background, Stone charts the increasing presence of magic in Dickens's work as enchantment becomes more sophisticatedly integrated with Dickens's portrayal of "reality," beginning with Pickwick Papers and continuing through 
David Copperfield (1850), in which, Stone argues, Dickens perfected his use of the fairy tale, and concluding with Great Expectations (1861). Stone, however, omits Bleak House (1853) from his discussion, saying, as one review summarizes it, that the other major works he analyzes "contain a great deal of autobiographical material and have, presumably, more facts, more "realism" to be used in the fairy tale manner" (Eigner "Review" 317).

Stone's aversion to analyzing Bleak House according to Dickens's biography and what Stone calls the "architectonic demands of fable" (115) may, therefore, be attributed to the fact that doing so would require him to summon a different critical apparatus than the one he seems to invent for his analysis of the other works. The need for a different mode of criticism arises from the fact that Bleak House is complicated, not only by Dickens's use of split narration, but by his employment, for the first and last time in his novels, of a female first-person narrator. The narratological problems posed by Bleak House have been avidly discussed by scholars. Most of this discussion has focused on the functions of and relationship between the omniscient third-person narration and Esther's first-person narration, a relationship which has been variously constructed as that of a parent and child (Sternlieb 79), as sororal (Wilt 285), and even as two sides of a single voice, both emanating from Esther (Schor 117; Newsom 87). More specifically, however, the narratological and gender issues that arise from Dickens's use of a female narrator have been investigated at great length. Generally criticized for her incessant key-jingling and excessive modesty, Esther's narration was dismissed as cloying and unrealistic until several scholars applied psychological principles to defend her unusual style. Arguing that Dickens's attitude towards Esther is “essentially clinical” (429), Alex Zwerdling, in his article, "Esther Summerson Rehabilitated" (1973), made the case that "the major aim of her portion of the narrative is to study in detail the short- and long-range effect of a 
certain kind of adult violence on the mind of a child" (429). This violence, caused by a deprivation of love (429) and the discovery of her illegitimacy (430), is registered in Esther's language as she gradually comes to terms with her childhood trauma. Similar contributions to the literature proved to be touchstones for critics, who began to describe and debate rather than disregard the significance of Esther's idiosyncratic narration.

Of primary concern have been the denials, gaps, and refusals of knowledge that permeate Esther's storytelling. Judith Wilt's “Confusion and Consciousness in Dickens's Esther" (1977) proposes that these narrative features are the result of Dickens's singular choice of narrator, in which choice he "found himself committed to the wider complexities of the Self-Other relationship, which are the female's lot in the world" (285). Taking Esther's troubles seriously, she suggests that Esther "[k]nows the limitations of her knowing" (297) and that Esther's confusion is therefore strategic, a "resourceful refusal to close in on judgment" (286). Less optimistic about the utility of Esther's narrative style, Joan D. Winslow (1976) has noted that Esther denies her imagination as a way of knowing truth (4). Conveyed through Esther's preference for certainty, this inhibition is a flaw that "causes a profound inadequacy in her way of understanding herself and her world" and "[cripples] her ability to deal with important personal crises" (2).

More recent criticism has connected Esther's narrative struggles more overtly to the gender politics of the text. Lisa Sternlieb, in her book The Female Narrator in the British Novel: Hidden Agendas (2002), takes into account, as few other critics do, the retrospective position from which Esther writes, arguing that her self-effacement is a conscious strategy that allows her to acknowledge without specifying her personal desires (76). However, Esther's retrospective position denies her imagination and therefore her ability to create new stories, a capacity that is granted to Dickens's male narrators, David 
Copperfield and Pip (77; 104). In contrast, Hilary Schor's Dickens and the Daughter of the House (1999) takes up Esther's narrative hesitations as symptoms of her narrative authority, of her ability to piece together and create her own identity; this authority, Schor argues, is the only inheritance she has received from her mother (123).

No discussion of Bleak House's narrative complexities, however, has connected the problems of Esther's voice with Dickens's cooption and integration of fairy tale motifs, elements, and characters into his work. Several scholars have laid the ground for such work, however, including Maria Tatar, Marina Warner, Nina Auerbach, and U. C. Knoepflmacher, who demonstrate that the history and tradition of storytelling is deeply entrenched in gender politics and bristling with tension over who can control the narrative act. Warner's work, especially her From the Beast to the Blonde: On Fairy Tales and their Tellers (1996), is committed to feminist readings, not only of the themes and details of popular fairy tales, but also of the history of storytelling as the history of a gendered struggle for cultural power. Maria Tatar likewise sees fairy tales as powerful means of culturation and socialization that can and have scripted readers' responses and desires, especially our culture's responses to women's desires for knowledge and power. Auerbach and Knoepflmacher have applied this thinking to Victorian culture and especially to Victorian writers. In their arguments, they often return to the thesis that male Victorian authors used the fairy tale form to freeze their female characters into the endless childhood they fantasized for themselves and their female audience (1).

Building on this scholarship, this paper explores how Dickens's use of a female narrator in Bleak House fundamentally problematizes and undermines his own use of the fairy tale's cultural cachet, motifs, and details to prop up his fantasies of the feminine ideal. More specifically, I will examine the effects of the thematic presence of several tale-types and stock fairy tale figures on Dickens's ability to prescribe ideal feminine 
behaviors, such as incuriosity and selfless obedience, to both his characters and audience. Because Esther's ability to write and her interest in either discovering or constructing her own identity establish her as competitor to the males who attempt to write her life, Dickens tries to control and circumscribe her ability to know and act through her own and other characters' resemblance to traditional fairy tale character types, especially Bluebeard and Griselda. Esther's narrative, however, betrays these unnatural delimitations in telltale interruptions and denials, the natural result of Dickens's attempts to circumvent the constraints he has placed on his heroine's voice. Esther's narrative therefore resists but imperfectly overcomes the Victorian male author's scripting of femininity. 


\title{
II. When Fairy Godmothers Are Men
}

\author{
"Storytelling makes women thrive."1
}

In Western Europe, tale-telling and -collecting, before Perrault's famous project, was a distinctly female way of passing information to members of the community and the next generation (Warner xvi). The "uses of enchantment" for women under patriarchal social constraints were real and practical: through tale-bearing, women could pass along information about cultural values (49). These traditions, however, were also threatening; morality tales prescribed that gossip, that most imprudent of vices, was to be shunned by wise women, who were depicted as wearing padlocks on their mouths (32). For while old wives' tales could "train children in attitudes and aspirations" (49), they did so informally, outside of institutions sanctioned by males (33). The information received by children and other women could, therefore, be subversive, and, indeed, it often detailed “women's secret knowledge of sexual matters that threaten[ed] established ideas" (42). A 1560 print depicting leering old gossips gathered at the bakers and at lyings-in while men and women brawl in the streets because of their loose talk points to the patriarchy's anxieties (33). Riot, chaos, revolution: these were the imagined outcomes of female taletelling.

Fairy tales were originally spread through these unofficial networks of female gossips. As literacy spread, however, these traditionally oral messages began to be transcribed into written forms and, as a result, began to transform in meaning. One reason

\footnotetext{
${ }^{1}$ Marina Warner, From the Beast to the Blonde: Fairy Tales and Their Tellers (New York: Noonday Press, 1996) xv.
} 
for this transformation was the new interference of men in the fairy tale's genealogy. While several popular and influential fairy tale collections were the product of a woman's pen, most notably Les Contes des Fées (1698) by Madame d'Aulnoy, they were generally less important to the fairy tale tradition than collections made by men, especially those by Straparola, the Grimm brothers, and Charles Perrault (Stone 24). Pointing out the reasons for her slight influence, Stone criticizes the stories of Madame d'Aulnoy for being much more contrived than Perrault's. Though they contained some folk materials and some borrowings ... they were largely attempts to create longish literary equivalents of fairy tales, an outgrowth of the somewhat précieuse French vogue of telling fairy stories to one another. (23)

In contrast, Stone praises Perrault and attributes the Frenchman's success to his tales' authenticity:

Perrault's fairy tales were real fairy tales taken from a living oral tradition. . . . Furthermore, though he told his tales with great art, he sought through that art to preserve their authentic flavor. He wished to transmit the tales, not turn them into sophisticated literary constructions. (24)

Stone's evaluation, however, is misleading. The publication of Perrault's fashionable and popular fairy tale collection, Contes $d u$ Temps Passé (1697), and the circulation of fairy tales in more formal, institutionalized venues had given men greater control over this feminine form of social power, and men could not resist making revisions to them that suited their own didactic purposes. Perrault's version of Bluebeard demonstrates how male-authored versions could recode what had once been subversive messages about female agency and power. Contradicting the straightforward transmission asserted by Stone, Tatar cites Paul Delarue as one scholar who has "mapped out the evolution of "Bluebeard," documenting the liberties taken by Perrault in transforming the oral folktale into a literary text" ("Introduction: Bluebeard" 142). Tatar elaborates on these liberties, which are subtle but telling. The savvy heroines of the folktale, who buy 
time by dressing in and "recounting each and every item" of their bridal clothes before the execution, are mocked by the repentant piety forced upon Perrault's heroine, who delays her death by asking for time to say her prayers (142). Likewise, many of the heroines from the oral tradition are the agents of their own rescue rather than damsels in distress relying on the punctuality of their brothers for salvation. However, perhaps of most importance, as Tatar asserts, is the fact that "folk versions of the tale do not fault the heroine for her curiosity. To the contrary, when the young women stand before the forbidden chamber, they feel duty-bound to open its door. . . . The pangs of conscience that beset Perrault's heroine are absent" (142). In every instance, the effect of the changes made by Perrault is to divert attention from the extreme violence perpetrated by the story's husband and to incriminate the wife and deprive her of power, agency, and knowledge. As if anxious that he was not able to thoroughly enough purge the subversive elements of female storytelling from his tale, Perrault appends the following moral to his version of Bluebeard:

O Curiosity, thou mortal bane!

Spite of thy charms, thou causest often pain

And sore regret, of which we daily find

A thousand instances attend mankind:

For thou, O may it not displease the fair, A flitting pleasure art, but lasting care, And always costs, alas! too dear the prize, Which, in the moment of possession, Dies. (Perrault 30) ${ }^{2}$

This moral hammers home, if the other changes did not, the redirected intention of the tale. No longer a tool through which women can make a "bold proclamation of the perils

\footnotetext{
${ }^{2}$ All references are to the first English translation of Perrault's story, published in 1729.
} 
of some marriages" ("Introduction: Bluebeard" 142) and openly explore alternatives, ${ }^{3}$ Perrault's version prescribes "proper" female behavior, becoming "a cautionary tale about women's innate wickedness" (Warner 244). This cautionary tale, however, is perhaps as much intended for males as for females; it provides men with a crash-course in the dangers of female desire, especially their desire for knowledge, which could expose the shaky, perhaps even brutal, foundations of the patriarchy.

It is not only the content of the (re)written tale that denies women social power, however. As mentioned above, the very act of setting them down in writing moved the oral tales into an unprecedentedly official position. The sphere of publication from which they newly exerted their ideological sway was one in which women had little power, either to alter the content of the tales or produce competing versions. A male hegemony, therefore, was able to inscribe its values onto traditionally female forms, attempting to co-opt the female voice by casting women as supporting players in the creation of their own work. ${ }^{4}$ As Auerbach and Knoepflmacher put it, "male redactors like Perrault and Grimm had appropriated and moralized the genre that was once associated with authoritative women ... whom male experts demoted to the status of mere informants" (6-7). Freezing women into the position of source rather than author, these narrative sexual politics condemned women to a state of perpetual mediation by men, who gave themselves unlimited license to authoritatively interpret and shape women's utterances.

Some scholars have even argued that this narrative power allowed men to textually shape women's growth and development, to circumscribe their bodies. Auerbach and Knoepflmacher argue that, by the Victorian period, male authors were

\footnotetext{
3 This assessment agrees with Marina Warner's suggestion that, in fairy tales, the "mood is optative, imagining what might be" (xx).

4 Tatar reminds us, "Although virtually all of the national collections of fairy tales compiled in the nineteenth century were the work of men, the tales themselves were ascribed to women narrators," a tradition that she traces back to the second century A.D. (Introduction $\mathrm{x}$ ).
} 
routinely using the fairy tale form to disseminate their own constructions of femininity in which women, already legally on par with children, lived out the fantasy of endless childhood the authors longed for (1). Women writers, however, had by the nineteenth century gained a position in the literary marketplace from which they could contest "male idealizations of a feminized innocence" and "wrest child-texts away from the fantasists who had come to dominate the market" (xii). These female authors, who seem to "chafe against childhood" (Auerbach and Knoepflmacher 1), wrote fairy tales that were "elliptical, subversive, open-ended" (8). As Knoepflmacher argues, "Their own imaginative constructs thus involve an indirect reappropriation of a literature that had once been their own" (xii). Through this reappropriation, they were able to revive and repropagate the original spirit and message of the oral folktales..$^{5}$ Imagining young girls as their audience (xi), male users of enchantment attempted to compete with this female community of storytellers, ${ }^{6}$ prescribing their fantasies and idealizations of female innocence and immaturity to a group of readers who had historically been nourished by tales.

Dickens is missing from Ventures into Childland: Victorians, Fairy Tales, and Femininity (1998), in which Knoepflmacher traces the differences between male and female uses of the fairy tale in the Victorian age, in part by closely examining the fairy tales of John Ruskin, W. M. Thackeray, George MacDonald, and Lewis Carroll.

\footnotetext{
${ }^{5}$ For examples of female-authored fairy stories, see Nina Auerbach and U.C. Knoepflmacher (eds.), Forbidden Journeys: Fairy Tales and Fantasies by Victorian Women Writers (Chicago: University of Chicago Press, 1992).

6 I refer here to both the traditional female storytellers and the professional women writers Knoepflmacher discusses in Ventures Into Childland, all of whom still exerted subversive power. The figure of the old wife spinning yarn and tales by the fireside continued in Victorian fiction, where she was often depicted as a female servant. According to Shuli Barzilai, such women were often seen as bringing "sensational and potentially pernicious material within the home" ("Charles Dickens" 22). Stone traces Dickens's own initiation into fantasy literature to the education he received from Mary Weller, a servant in the Dickens house. Mary would entertain and frighten young Dickens with ghoulish, fantastic stories, including one that became the basis for his Bluebeard adaptation, "Captain Murderer" (34).
} 
However, Dickens undoubtedly joins these male authors in projecting a feminine ideal in his own work that reflects his personal predilections for nostalgia and stasis. It is not a coincidence that it is in his writings about children's literature that this intention is first revealed by Dickens. These essays are marked by a longing for an Edenic past, to which he somehow hopes, through literature, to return and in which he desires that he-and all children-can forever remain. In 1853, while writing Bleak House, Dickens published an essay in Household Words tellingly entitled "Where We Stopped Growing." It begins, "Few people who have been much in the society of children, are likely to be ignorant of the sorrowful feeling sometimes awakened in the mind by the idea of a favourite child's 'growing up"” (385). He explains, "Childhood is usually so beautiful and engaging, that . . there is a mournful shadow of the common lot, in the notion of its fading into anything else" (385). Already betraying both a tendency to idealize childhood as some golden age and a yearning to constrain children in eternal immaturity, Dickens soon demonstrates that he can go beyond simply wishing for this impossible feat, for he has the actual ability to arrest even adults in their growth and send them, piecemeal, back to youth. The tools with which he performs this operation are the literary works of one's childhood: after his nostalgia has led him to consider "whether there were any things as to which this individual We actually did stop growing when we were a child" (385), he, much to his relief, is able to enumerate a long list of these suspensions in his development, each associated with a favorite story whose details retain such a strong hold on his imagination that they have actually prevented him from developing any new conceptions regarding them as he has aged. This is one way in which, as Dickens wistfully asserts in "Frauds on the Fairies," also published in 1853, "stories help keep us, in some sense, ever young, by preserving through our worldly ways one slender track not overgrown with weeds, where we may walk with children, sharing their delights" (56). 
It is clear, however, that Dickens does not just want to walk with children, he wants to become one, and this same nostalgia worked with a vengeance on the women in his life and books. Shuli Barzilai has theorized that the passing of his sister-in-law, Mary, whose early death allowed her seventeen-year-old self to be eternally "cherished in its changeless purity" in Dickens's mind ("Bluebeard Barometer" 513), inspired in him a feminine ideal that was "an abiding ghost, always youthful, virginal, and fair" (513), much like an Alice trapped in her author's own dream (Auerbach and Knoepflmacher 6) or a Snow White, perfectly preserved in her glass coffin. Barzilai claims that Dickens's uses of the Bluebeard fairy tale in his novels are ploys that hide the palimpsest of the desires and fantasies that underlie his work. Like other male authors of his day, it is indeed through stories that he would attempt to keep women, not just ever young, but the indefatigable angels of the house who give all and ask nothing in return ("Charles Dickens" 32$){ }^{7}$

Esther Summerson does not escape Dickens's authorial projection of this desire. In Esther, as Alex Zwerdling asserts, "Dickens is interested in portraying someone who remains trapped between childhood and real maturity" (429). It should come as little surprise, therefore, that when Dickens introduces his first female narrator, he positions her immediately within the fairy tale tradition. In but the third paragraph of Esther's narrative, she begins her own "once upon a time": "I was brought up, from my earliest remembrance-like some of the princesses in the fairy stories, only I was not so

\footnotetext{
${ }^{7}$ Dickens is aided in this endeavor by several interesting adaptations of his work. In one series published in America called Dickens' Little Folks, a volume entitled Dame Durden: Little Woman from the Bleak House of Charles Dickens (1878) venerates Esther as an "elder sister" whose excellent example should instill similar virtues in those who read of her exploits (Preface v). Consisting wholly of Esther's narrative from Bleak House, the book visually represents the aspect of Esther's character it wants most to emphasize before the text even begins: an illustration facing the title page shows a modest Esther being presented with her housekeeping keys.
} 
charming - by my godmother" (BH 28).$^{8}$ From the first, then, Esther is complicatedly both a teller of and an actor in a fairy tale that must negotiate two traditions, one in which, as a female storyteller, she is entitled to an authoritative voice that grants herself, as an actor, agency and options; and another in which Dickens must control her voice to express certain desires, attitudes, and values that a female storyteller could not realistically be expected to communicate. ${ }^{9}$ For a Victorian author like Dickens, these narrative politics make his use of female narrator an almost acrobatic venture, ${ }^{10}$ one in which he must bring her to the forefront but always stand in her way, develop her and yet keep her miraculously stunted. Esther is akin to the female writers of her day competing with the likes of Lewis Carroll, who desired so strongly to keep his "beloved dream child," Alice, "ever enshrined in 'happy summer days' unaffected by change" that he indulged "in fantasies of containment and domination that were totally inimical to [the female authors'] own yearning for autonomy and authority" (Auerbach and Knoepflmacher 6).

Dickens is able to perform these gymnastics, however, by making Esther a character, not just in her own narration, but in another's narration as well. By splitting this representation of her, Dickens momentarily silences Esther and makes her subject to larger considerations of genre, plot trajectory, and identity, the terms of which Dickens gets to set and within which her narrative is then forced to operate. This explains, in part,

8 The effect of this statement in Dame Durden is striking, coming as it does only three paragraphs from the beginning of the book and without having been imbedded in the third-person narrative and its subsequent interruptions.

${ }^{9}$ Dickens's difficulty was summed up by George Brimley's review in the Spectator, which snidely observes that a girl like Esther, or at least the type of girl she was supposed to be, "would not write her own memoirs" (qtd. in Wilt 287).

${ }^{10}$ Wilt remarks that, indeed, "the book strove against him rather more than he looked for" (285), citing John Forster's report that Dickens complained uncharacteristically of overwork during the novel's composition (285n1). It appears that Dickens had to take remedial measures against this fatigue; the summer of 1853 found him in Boulogne, where he had arrived "badly overworked," having been "chained to Bleak House for a year and a half" (Stone 1). 
why the book opens, not with Esther's "portion of these pages" (27), but with the thirdperson narrator, who irresistibly establishes his authority by employing the same telegraphic style a playwright would use to write stage directions. By being inscribed in this way, Esther is prevented from using the fairy tale form on her own terms, is prohibited from writing herself as an actor who, as Tatar argues of Jane Eyre, could become "a one-woman crusade and act of resistance to the roles modeled for girls and women in fairy tales" (Introduction xvii), specifically, I would clarify, male-authored fairy tales. Denied the ability to make "productive use of fairy tales by reacting to them, resisting them, and rewriting them" (xviii), Esther instead has Dickens's own rewriting imposed upon her. This bind begins to explain the observations of critics who have sought the source of the syntactical hiccups that stilt her narrative. Sternlieb's conclusion that Esther can write, but not creatively or imaginatively (104) and Winslow's statements that Esther continually denies her imagination as a way of knowing truth (4) merely point out symptoms of Dickens's struggle to both grant and strategically withhold Esther's feminine fairytale heritage.

One of the fundamental ways that Dickens inscribes Esther within fairy tale scripts is by embodying certain stock fairy tale figures in his characters. Particularly useful to Dickens is the godmother figure or "Benevolent Agent," as Edwin M. Eigner calls her, who was probably modeled on the old wife, the female storyteller. ${ }^{11}$ The fairy godmother's descent from the female storyteller explains why, traditionally, the fairy godmother exerts a kind of authorial control over other characters, changing their natures or directing their fates. Importantly, fairy godmothers in folk tales are frequently implicated in what Victorians called the "pious fraud," a lie told for a moral end (Eigner

\footnotetext{
11 The Benevolent Agent Eigner describes was a stock figure from the Pantomime. However, as Kotzin notes, "As a child, Dickens may have confronted fairy-tale material in plays, pantomimes, and toy theater productions" (34); the Pantomime was strongly rooted in the fairy tale tradition.
} 
54), usually to shape or "assess the character of the person being tested" (53). Appropriating this female authorial role for a male, Dickens casts Mr. Jarndyce in the role of fairy godmother, using him to "write," or direct, Esther's life. He magically appears and vanishes several times, most memorably in the carriage carrying young Esther to Greenleaf (36-38), before revealing himself to be the noble benefactor and architect of the "six quiet, happy years" (39) she spent at that school. The book culminates in his pious fraud, in which he delays telling Esther that he plans to allow her to marry Allan Woodcourt so that her future mother-in-law can have time to observe and be assured of Esther's good character. As he puts it, "I would not have my Esther's bright example lost; I would not have a jot of my dear girl's virtues unobserved and unhonoured" (964). As a reward for passing her test, Esther gets to marry the man she loves and inherits a second Bleak House, appointed and prepared by Mr. Jarndyce.

The benevolence of Mr. Jarndyce's deft manipulation of Esther's life at this juncture has been praised by critics, who have lauded him as a "moral superman" (qtd. in "Bluebeard Barometer" 514) and a true "fairy godmother" (515). His benevolence becomes questionable, however, when we acknowledge, as I have delayed doing, that Jarndyce is not a fairy godmother, but a godfather with matrimonial designs on his "godchild," essentially altering the dynamics of his test and leaving it fraught with inequalities of social and gender-based power. In his position as fairy godmother/father, Jarndyce acts in the father's domain, which in fairy tales, Tatar tells us, is "[c]ontrol of marriage, and hence the regulation of desire and sexuality," but also usurps the mother's domain, "the organization of the domestic sphere, which also determines the availability and desirability of daughters" (Off with Their Heads! 137). His assumption of this maternal duty is plain in Mr. Jarndyce's gift to Esther of the housekeeping keys ( $\mathrm{BH} 88)$, which transforms her into the "best little housekeeper" (961) and therefore a suitable 
marriage partner. The keys, however, also have a disciplinary aspect that works to regulate Esther's desires and feelings. Having brought the keys with her to her first interview with her Guardian, she uses them to suppress emotions she knows will make Mr. Jarndyce uncomfortable: "I felt that I was choking again-I tasked myself with it. . . But I gave the housekeeping keys the least shake in the world as a reminder to myself, and folding my hands in a still more determined manner on the basket, looked at him quietly" (120). As the keys become reminders of her debt of gratitude and therefore dutybound position toward Mr. Jarndyce, they also regulate her desires for knowledge, which are typically expressed in that most feminine of vices (Off with Their Heads! 111), curiosity. As if to test her, soon after she is given the housekeeping keys, she is let into Mr. Jarndyce's confidence and is especially charged with discretion with respect to the information he gives her $(B H$ 120). She is simultaneously asked if there is anything she would like to know about her past (122). She immediately denies her own desires and defers to his prerogative, suppressing her curiosity by replying, "Nothing! I am quite sure that if there were anything I ought to know, or had any need to know, I should not have to ask you to tell it to me" (122).

Through these means, Esther is made to act like the ideal woman. She becomes, in fact, very much like the most desirable bride the prince in Perrault's version of Griselda can imagine: "a woman who has never shown / the slightest disobedience: she must be / Of proven patience, modest, lacking pride, / And free from any wishes of her own" ("History of Griselda" 14). In the Griselda story, a king or prince refuses to marry any but the most submissive, humble, and obedient wife. Generally joined in matrimony to a girl from the lower classes who displays such traits (in Perrault's version the bride is a shepherdess), the husband then begins a test, a sort of pious fraud, in which her longsuffering is observed through a series of appalling trials, including abandonment by 
her husband and separation from her children. She endures with such patience that her husband is won back to her and she is restored to her former enviable position. Mr. Jarndyce's gift of the keys and his pious frauds write Esther into a Griselda story, forcing her to enact the same behaviors as the tale's heroine when faced with similar tests. Consider, for instance, the similarity between Esther's complete deferment to $\mathrm{Mr}$. Jarndyce, above, and Griselda's immediate agreement to the terms of her marriage with the prince:

"But you must swear, for peace to reign

Eternally between yourself and me, Henceforward to obey my will alone."

"I swear," she answered; "I have always known, Although the man I married might be poor, That on all matters he would then decide, And I obey with joy; how much the more If you, my lord, should take me for your bride!"” ("History of Griselda" 22)

Further resemblance between Griselda and Esther surfaces when Esther, like Perrault's heroine, is required to pass through a test of her fidelity in the face of her own betrayal. In Perrault's tale, the prince recalls his wife from her banishment to serve the lovely maiden he has chosen to replace her (who also happens to be their daughter). The full effect of this test is achieved in Bleak House through a constellation of events. Unaware that Mr. Jarndyce was apprised beforehand of the proposal (965), Esther receives a declaration of love from the man she prefers to marry but nevertheless begins "very quietly to make such preparations as I thought were necessary" ( $\mathrm{BH}$ 959) for her impending marriage to Mr. Jarndyce. In addition, just as Griselda is forced to turn over to her usurper all that had once been hers, Esther is asked to offer her advice about Mr. Jarndyce's gift to Woodcourt, a house in which she sees, in all of its appointments, "my little tastes and 
fancies, my little methods and inventions . . my odd ways everywhere" (963). This Griseldan sacrifice, in which she is forced to admire and serve where she has been dispossessed, calls the same reaction from Esther as it does from Griselda. Esther matches Griselda's concern for the potential queen, whom Griselda begs the prince not to mistreat as he has her, with her own concern for Mr. Woodcourt, whom she fears the evidences of her housekeeping style might remind "mournfully of what he believed he had lost" (963).

Esther's actions, then, mimic Griselda's, and just as Griselda becomes the woman in which the virtue of patience is "shown / In perfect form by her alone" ("History of Griselda 41), Esther's forbearance causes her to be celebrated as a "pattern young lady" (BH 958). The word "pattern" here denotes both Esther's desirability as a model to be imitated and the artificiality of her construal as such, suggesting that she has been made after a pattern, as indeed she has. For, like Perrault, Dickens has attempted to "enlist the consciousness of [his] readers in the effort to foster patient suffering as the preferred modality of power for women" (Off with Their Heads! 108), a moral that could never have sprung from the tradition of female-authored fairy tales. In fact, the Griselda story, in Perrault's telling, is premised on the male desire for authority over the female: "WWhat I myself am certain of is this,", declares the prince, "“for there to be a chance of married bliss, / Authority must not be shared by both [spouses]"” ("History of Griselda" 13-14). But while Perrault, whose omniscient third-person narrator has no difficulty in drawing the aphorism, "“These torments are for me . . . a test: / My husband makes me suffer in this way / To rouse my virtue, which too long a rest, / I know, would cause to perish and decay. / . . We ought to love the pains we bear: / to suffer brings us future joys"” (27), from the stoic Griselda, Dickens must resort to all sorts of wiles, especially key jingling, to make his female narrator believably compliant during similar moments of trial. 
Before I address the idiosyncrasies of Esther's narration in more detail, however, I must address the slippage into the role of husband that Mr. Jarndyce, as a fairy godfather, performed during my discussion of the Griselda tale. As in Bleak House, the boundaries between father and husband are demonstrably unstable in fairy tales. "Donkeyskin," "Catskin," and a host of other tales ${ }^{12}$ feature fathers who offer marriage to their daughters. In Dickens's novel, Mr. Jarndyce's role as (potential) husband is essential to his ability to play the role of benevolent father, not only because it provides a pretext for his pious fraud, but also because it allows him to reserve her in a maturational holding pattern until he, as the godfatherly marriage broker, can see her safely into the right marriage. This dual role is convenient for Dickens, whose resistance to female growth I have already discussed: it precipitates in Jarndyce's tardy release of Esther from their engagement, a move that stalls the fulfillment of her desires and the progress of her development until practically the moment it becomes, because of the marriage plot, inescapable. Esther's ability to endure self-denial is crucial to this scheme. Attentive to the lessons of the keys and following after the pattern of Griselda, Esther submits to this new embarrassment to her desires and does not admit her feelings until sanctioned to do so by Mr. Jarndyce: after bringing her to Mr. Woodcourt's new house, he asks her, "Full of curiosity, no doubt, little woman, to know why I have brought you here?" She replies, "Well, guardian, without thinking myself a Fatima, or you a Blue Beard, I am a little curious about it" (961).

\footnotetext{
12 Tatar classes these stories as "Cinderella" variants in The Classic Fairy Tales. The difference, she writes, is that "Cinderella" tales are "driven by the anxious jealousy of biological mothers and stepmothers"; "Catskin" variants are "fueled by the sexual desire of fathers, whose unseemly behavior drives their daughters from home" ("Introduction: Cinderella" 102). The daughters in "Catskin" tales escape their fathers and endure trials to find a suitable marriage partner.
} 
It is no accident that Esther alludes to Bluebeard, another fairy tale narrative in which she has been trapped, in this moment of great duress. ${ }^{13}$ As Barzilai observes, "wherever this motif emerges in [Dickens's] writings, and no matter how seemingly humorous or benign the reference, darker atmospheric components may also be found" (29). Under the circumstances, Esther is more a Fatima than a Griselda, admitting, as she does, her desire to understand motives and to gain more control over her own story. If, through the Griselda tale, Dickens strives to make Esther into the angel of the house who serves asking nothing in return, it is through the Bluebeard tale that he tries to keep her innocent and immature, to make her stop growing by putting her in a plot in which examination and knowledge of her own desires for the purposes of increased understanding and romantic fulfillment would terminate in decapitation. It is not a major leap, either, between one husband's masochistic cruelty and another's when the only essential difference is that one intends to reward while the other intends to punish. As a Bluebeardian husband, Mr. Jarndyce is one of the primary agents of Dickens's folkloric forbidding, though he is joined in Bleak House by several other Bluebeards, who also exert their control over Esther's actions.

Even while these Bluebeards employ a male rendering of Bluebeard to carry out Dickens's campaign of infantalization against Esther, they are competing with a female fairy tale tradition surrounding the tale that was very much present, even in Perrault's

\footnotetext{
13 Shuli Barzilai's research has revealed that "Blue Beard," extremely popular in England after Perrault's tales were translated into English in 1729 ("Charles Dickens" 159n4), received special attention from Dickens (23), who made references to it in most of his works and even wrote his own parodic version about a man named Captain Murderer (23). Barzilai's Tales of Bluebeard and His Wives from Late Antiquity to Postmodern Times (2009) is the first study to unearth and closely examine Dickens's overt and frequent references to this bloody fairy tale. While Barzilai demonstrates how this fantasy informs Dickens's depiction of Esther Summerson, who she says passes her Bluebeardian bride-test in Bleak House (1853) with unflagging loyalty and self-sacrifice, Barzilai's main point in using it is to examine the triangulated relationship resolutions present throughout Dickens's works, resolutions that are a projection of his own "fantasy of incestuous conjugality" ("Bluebeard Barometer" 515).
} 
version. Clarissa Pinkola Estés, a Jungian analyst, has revitalized the female uses of the Bluebeard story in her Women Who Run With the Wolves: Myths and Stories of the Wild Woman Archetype (1995). In this study, she renews women's access to their storytelling roots, empowering them to use archetypal tales to explore options for healing and making healthy life choices. "Story solutions," she declares, "elicit doses of adrenaline at just the right times, and ... cut doors into walls which were previously blank" (61). She points out the rift between male uses of fairy tales and female uses, which exist even in her field of psychoanalysis:

Some psychological thinkers, including Freud and Bettelheim, have interpreted episodes such as those found in the Bluebeard tale as psychological punishments for women's sexual curiosity. Early in the formulation of classical psychology women's curiosity was given quite negative connotation, whereas men with the same attribute were called investigative. . . In reality, the trivialization of women's curiosity . . . denies women's insight, hunches, intuitions. . . . It attempts to attack her most fundamental powers: differentiation and determination. (47-48)

Referring to the key the heroine uses to open the door to the bloody chamber, Estés declares that female uses of the Bluebeard story are able to "[raise] to consciousness the psychic key, the ability to ask any and all questions about oneself, about one's family, one's endeavors, and about all around" (61). ${ }^{14}$

Traces of this female tradition are still discernible in Perrault's version. The Bluebeard story's typical elements include a monstrous husband who murders his curious wives after they learn a secret they were forbidden to search out. Its moral is consistently,

\footnotetext{
${ }^{14}$ Feminist critics, who were among the first to explore how the fairy tale has informed the social and sexual development of characters in Victorian fiction, have even pointed out ways in which the traditionally female uses of fairy tales can help men in their life choices. Sandra Gilbert, in her essay "Jane Eyre and the Secrets of Furious Lovemaking" (1998), suggests that the Bluebeard tale provides a frame in which to interpret "the mystery of male sexuality" (363) posed in the novel. In her argument, the male figures that Rochester and Jane encounter in the course of the book offer Rochester "virtuoso variations on the theme of Blue Beard to represent the life options available to Rochester," alternatives that range from "masochistic self-abnegation" to "sadistic passion" (363).
} 
as Estés affirms, the condemnation of curiosity, which is figured in the tale as a morally dangerous, transgressive pleasure or passion, especially because it admits women's desire - and ability - to gain access to forbidden knowledge. In the tale, in fact, the wife's curiosity becomes the means of detecting, exposing, and condemning the kinds of male cruelty evident in stories like "Griselda." The Wife's curiosity, which impels her to open the door her husband warns her to never look behind, reveals the "bodies of several dead women ... all the wives that the Blue Beard had married and murder'd one after another" (Perrault 23). When Fatima is rescued, Blue Beard is killed, and as his heir, Fatima assumes the responsibility for redistributing and managing his wealth. Like Jane Eyre, who can proclaim at the close of her narrative, "Reader, I married him" (Brontë 552), Fatima's revolution allows her the autonomy to "marry herself" to the man of her choice, to set up her brothers' careers, and to give away her sister in marriage, deciding the fates of herself, her siblings, and the money that has come under her control. By telling the story, not of the wives who are found dead in the bloody chamber, but of the young lady who is rewarded for her curiosity by her husband's death, the tale "reveal[s] possibilities, [and] maps out a different way and a new perception of love, marriage, women's skills, thus advocating a means of escaping imposed limits and prescribed destiny" (Warner 24). Perrault's version scrambles to preclude this reading of the story, appending a moral (see above) that reinforces the male reading of the story in unmistakable terms. The potential "Blue Beard" reveals for a woman's desire for knowledge to lead her to an autonomous adult life makes it essential for the Bluebeards Esther encounters to keep her from this secret by reinforcing, through overt proscriptions and psychological manipulation, the version of the tale that will keep her from her rightful inheritance of selfhood.

The dangers of feminine desire are recognized by the first Bluebeard that the reader-and Esther-encounters in the novel: Esther's first guardian, her aunt Miss 
Barbary. Miss Barbary's name not only invokes images of exotic barbarism, such as that thought to exist amongst Moorish peoples and exhibited in Bluebeard, ${ }^{15}$ but also the word "beard" itself, which is rendered la barbe in the French tongue. Like Bluebeard, she is the guardian of a secret about the results of female desire, one that she tries to keep from the dependent girl in her charge. For the results of Lady Dedlock's affair with Captain Hawdon were, it seems, not simply the tragic circumstances into which Esther was born, but also the source of enough "pride, ambition, insolent resolve, and sense" to motivate Lady Dedlock to marry a baronet, despite having no connections, and to climb to "the top of the fashionable tree" ( $B H$ 22). Indeed, Lady Dedlock implies that the results of her passion taught her self-determination, if only through expediency, when she speaks to Esther for the first and last time: "To hope to do what I seek to do, I must be what I have been for so long. Such is my reward and doom" (582). The secret, guarded by Miss Barbary, is one that Victorian society needs her to keep so that its construct of femininity and masculinity, in which women were "politically, economically, legally, and erotically disempowered" (Gilbert 358) and men were allowed "public power but also . . . fatal private knowledge of sexuality" (358), could persist. Because she is female, Miss Barbary, armed with this "fatal private knowledge," has revolutionary potential, nascent "public power" to destabilize her society's construct of male and female desire-and therefore male claims to power. Traditionally, this female caretaker figure would initiate Esther into such knowledge through tale-telling, and Miss Barbary's status as a godmother indicates that this should be her role. Dickens, however, is unwilling to give

\footnotetext{
15

Illustrators often depicted Bluebeard as a Turk or Arab. The beard was indicative of filthiness and lust, and Christians historically associated both beards and lechery with Saracens or Muslims (Warner 242). Such a characterization of Oriental peoples was typical in European thought; Rana Kabbani has noted that the two most common claims Europeans made about the East were that it was a place of "lascivious sensuality" and "inherent violence" (qtd. in Barzilai 160n13).
} 
Esther the opportunity to learn and follow the subversive plot lines laid down in women's stories. In typical Bluebeard fashion, Miss Barbary kills the female in herself to keep the secret from spreading, becoming desexualized and desocialized through her rejection of Boythorn's marriage proposal and her self-imposed antisociability. She herself referred to this process as a death, writing to Boythorn "that from the date of that letter she died to him" (686). Repressing and abstaining from personal knowledge of female desire, she becomes a woman "always grave, and strict" (BH 28) and "stiff" (29), one with whom Esther "never could be unrestrained" (28), a vessel, in other words, that cannot be breached, like the bloody chamber locked forever by its master. ${ }^{16}$

At times, as Estés acknowledges, "this keeping a woman in line by her female peers and older women lessens controversy and enhances safety for women who must live under hostile conditions. Under other circumstances, however, this psychologically pitches women into full scale betrayals of one another" (Estés 492n). Miss Barbary’s strictness hardly protects Esther. In fact, Miss Barbary wishes her dead, or at least never born ( $\mathrm{BH} 30)$; Esther, problematically for Miss Barbary, is an uncontainable sign of the secret, especially in her likeness to Lady Dedlock, which, like Fatima's permanently bloodied key, is easily read by the other characters. Miss Barbary, therefore, closely contains Esther, whom she attempts to desocialize by preventing her from forming friendships with her classmates (29) and raising her in secret. This effort is combined with an effort to desexualize Esther-an attempt to replicate the femicide Miss Barbary practices on herself.

16

Female Bluebeards are less common but not unknown. In the Grimm's version of the Bluebeard tale, called "Marienkind," the Virgin Mary fills the role of Bluebeard and "savagely punishes the wayward girl who uses the forbidden key" (Warner 244). 
Miss Barbary's betrayal closes Esther into the "architectonics" of the maleauthored scripts, and Esther is given, instead, incomplete and disrupted narratives about her own social and sexual possibilities. She is raised in an entirely female household into which the mention of males or fathers never comes. In fact, the obsession with mothers, despite its focus on their guilt, produces a declaration from Miss Barbary that practically implies a miraculous, virgin birth: "You are different from other children, Esther, because you were not born, like them, in common sinfulness and wrath. You are set apart" (31). Moreover, Esther is schooled to be appetiteless and passionless; "submission, self-denial, diligent work" (30) are the virtues she is taught to develop. Importantly, however, Esther also learns to deny herself the satisfaction of her curiosity after her questions about her mother are answered with a close-lipped, "Esther, good night!" (29) by Mrs. Rachael and her pleadings to be told about her past prompt Miss Barbary to reply, "Ask me no more, child!”. Her guardian follows up with a terrifying lecture about disgrace and degradation (30). For Esther, Miss Barbary's sermon is not one against sexual deviance, which she knows nothing about, but is a warning not to ask questions. ${ }^{17}$ Like Bluebeard, Miss Barbary "forbids the young woman to use the one key that would bring her to consciousness. To forbid [this] strips away ... her natural instinct for curiosity that leads her to discover what lies under" (Estés 47). This key, again, is the "ability to ask any and all questions about oneself . . . and about all around" (61). Esther, written into a tale in which to ask questions is equivalent to losing one's head, cannot hope to discover that, as Estés puts it, "by choosing to open the door," that is, uncover the secret, "she chooses life" (47).

17

The two have a long history, however, of being inextricably connected: "The principle sin ... with which the tongue is connected is lust. . . The tongue is seduction's tool" (Warner 47). Notably, Eve herself was a victim of a tale-telling serpent. 
Miss Barbary's death makes the secret about the existence and power of female desire less containable by allowing Esther to circulate socially. It is therefore far more important that Esther internalizes a message decrying curiosity — desire for knowledgethan any passive messages she may receive about sexual desire. It is through curiosity that Esther would become aware of the transgressive power she yields to bear testimony of the illegitimacy of Victorian gender ideologies perpetuated by male-authored fairy tales. However, Esther has been well trained to contain the circulation of secrets. She therefore continues Miss Barbary's course of disacknowledging female desire, though not, of course, to purposefully disempower herself as her "godmother" did. The result of this repression is Esther's confused but slavish devotion to "submission, self-denial, diligent work." The direct link between her desire for self-knowledge (curiosity) and her compulsion to repress it through self-denial and work is apparent in a scene that follows Mr. Woodcourt's pre-voyage farewell, when Esther tells her reader,

It would not be worth mentioning for its own sake, but I was wakeful and rather low-spirited. I don't know why. At least I don't think I know why. At least, perhaps I do, but I don't think it matters. At any rate, I made up my mind to be so dreadfully industrious that I would leave myself not a moment's leisure to be lowspirited. (BH 274)

Mr. Jarndyce, as Esther's next Bluebeard incarnation, has only to pick up where Miss Barbary left off. The first thing she is given by this new guardian is a set of keys, the exact object entrusted to Fatima when she becomes a member of Bluebeard's household. For both women, this trust opens many doors: Fatima is given access to all the wealth her husband has, and Esther becomes mistress of a household, the apogee of a Victorian woman's career. This opportunity to make decisions and accept responsibility could initiate Esther into womanhood. As has been discussed earlier, however, it has the opposite effect, becoming a reminder of the bounds within which her knowledge and 
desires for knowledge must stay. From the first time she defers her right to knowledge, her further actions in the novel demonstrate that she has internalized this policy, first ingrained in her by Miss Barbary and continually reinforced by Mr. Jarndcye, until her refusal of knowledge has become virtually a reflex. For instance, when Mr. Boythorn's behavior prompts her to ask her guardian if Mr. Boythorn had ever been married, she is answered no, but venturing to ask if he was supposed to have been, she cannot help "reddening a little at hazarding what was in [her] thoughts" (147). Her blush signals that she is alert to some risk in reaching after knowledge, particularly on a topic that has been taboo from her youth, and after a brief and vaguely informative exchange with $\mathrm{Mr}$. Jarndyce, she reports, “I felt, from my Guardian's manner, that beyond this point I could not pursue the subject without changing the wind [upsetting Mr. Jarndyce]. I therefore forbore to ask any further questions. I was interested, but not curious" (147). This softening of her desire for knowledge ${ }^{18}$ is evidently the result of a trying self-discipline; it is not a coincidence that she "dreamed of the days when I lived in my godmother's house" that night (147).

By casting her as a Fatima and guarding her closely with Bluebeards, Dickens successfully withholds from Esther the growth and development that could come with increased understanding about her world, her past, and her possibilities. This stunting is reflected in the names Mr. Jarndyce assigns to her, names that pun on her stewardship over the keys. His favorite appellation, "little woman," derives from "the little old

\footnotetext{
${ }^{18}$ Esther has evidently saddled the word curiosity with a negative connotation, a move that is not necessarily a foregone conclusion. The Oxford English Dictionary's entry on "curiosity" divides the fifth sense in which it is used, "Desire to know or learn" (def. 5), according to its "blamable sense" (def. 5a) and its "neutral or good sense" (def. 5b). In its blamable sense, it means "The disposition to inquire too minutely into anything; undue or inquisitive desire to know or learn" (def. 5a). In its neutral sense, however, it is virtually indistinguishable from being interested: "The desire or inclination to know or learn about anything, esp. what is novel or strange; a feeling of interest leading one to inquire about anything" (def. 5b).
} 
woman of the Child's . . Rhyme" (121). ${ }^{19}$ Additional names by which she was thereafter called include Old Woman, Little Old Woman, Cobweb, Mrs. Shipton, Mother Hubbard, Dame Durden, "and so many names of that sort, that my own name soon became quite lost among them" (121). These names, especially "little woman," belittle Esther, effacing her own identity and diminishing her to a static type or even a pet. Importantly, these identities to which she is obligated to conform are those of old women, archetypes beyond the possibility of growth and change and safely beyond desires or being desirable.

Besides Esther's “without thinking myself a Fatima, or you a Blue Beard” (961), this name-giving is one of Dickens's most overt efforts to assign Esther roles that will stifle her growth. At least one more person in Bleak House is assigned the role of Bluebeard toward Esther, however, and the designation is made just as overtly as these previous designations. This person is Mr. Bucket, whom Volumnia Dedlock refers to as “a perfect Blue Chamber" (813), which, in his delayed revelation of dead female bodies, he indeed is. Esther is placed into Mr. Bucket's hands at a moment when the secret about her mother's indiscretion is made public knowledge. This is a moment when narrative control of Esther is crucial; if Esther were to openly become her mother's daughter, her life options would differ radically from those prescribed by fairy tales like Griselda and Bluebeard. She would become a Cinderella ascending to the throne with the aid of her mother instead of by the condescension of a prince, an heiress after the style of Jane Eyre. She would, in fact, be transferred into female versions of the Bluebeard tale, in which male desires for domination are highlighted as bloody cruelties. ${ }^{20}$

\footnotetext{
${ }^{19} \mathrm{Mr}$. Jarndyce here quotes the following rhyme: "Little old woman, and whither so high? - / To sweep the cobwebs out of the sky" (BH 121).

${ }^{20}$ For instance, in Angela Carter's version of Bluebeard, entitled "The Bloody Chamber," it is the "sheer carnal avarice" (11) of the leonine husband that takes center stage, and his brutality is highlighted in the sadistic delight he takes in his bride's sexual innocence, humiliating her on their wedding night. The wife, as narrator, confides that she "could not but flinch from [his] intimate touch" after discovering the bloody chamber, "for it made me think of the piercing embrace of the Iron Maiden and of his lost lovers in the
} 
The presence of Mr. Bucket, however, insures that the manner in which the secret is revealed neither teaches Esther how to ask questions nor starts her down the path of self-knowledge. The inspector requires her presence at his investigation but with Bluebeardian perversity forbids her from asking questions about his methods: "My dear . . . don't you fret and worry yourself no more than you can help. I say nothing else at present; but you know me, my dear; now, don't you?” (BH 885). Their journey around London becomes a prolonged "bride-test" that reinforces Esther's blindness and applauds the suppression of her curiosity. Though she suffers mentally and physically from the strain of unanswered questions, she remains obedient: "I could eat nothing, and could not sleep; and I grew so nervous under these delays ... that I had an unreasonable desire upon me to get out and walk. Yielding to my companion's good sense, however, I remained where I was" (881). Her fatigue is strongly contrasted with the energy with which Mr. Bucket's questioning enlivens him:

All this time, kept fresh by a certain enjoyment of the work in which he was engaged, he was up and down at every house we came to; addressing people whom he had never beheld before, as old acquaintances; running in to warm himself at every fire he saw; talking and drinking and shaking hands. (881)

In Mr. Bucket, whose name prophesies his containing role, male curiosity is clearly institutionalized and sanctioned. ${ }^{21}$ This unmistakable double standard makes his approval of Esther all the more pointed; her finest attribute is perfect obedience:

vault" (34). In a subversive twist, it is the girl's mother who rescues her daughter, arriving on horseback to shoot the diabolical groom just as he is about to execute the young woman. Her arrival interrupts his script as Lady Dedlock's survival might have Dickens's: "The puppet master . . . saw his dolls break free of their strings, abandon the rituals he had ordained for them since time began and start to live for themselves" (39).

21 Tatar chafes against this bias, in which "female curiosity is . . tainted with evil, while male curiosity is enshrined as a virtue" (Off with Their Heads! 111). Readings of the bloody key as a marital infidelity or as the irreversible loss of virginity or innocence she condemns as "willfully wrong-headed in [their] effort[s] to vilify Bluebeard's wife" ("Introduction: Bluebeard" 141). 
If you only repose half as much confidence in me as I repose in you, after what I've experienced of you, that'll do. Lord! You're no trouble at all. . . . When a young lady is as mild as she's game and as game as she's mild, that's all I ask. (902)

Inspector Bucket's absolute control over the investigation guarantees his control over the secret, and Sir Leicester's promise of forgiveness has ensured Lady Dedlock a safe return to the patriarchal status quo after she is caught. Esther can make no personal use of the secret for her own empowerment; it is instead carefully contained by a group of authoritative males who have an interest in her continuing to reject it. By the time $\mathrm{Mr}$. Bucket relieves the suspense she has labored under by satisfying her curiosity about her mother's fate, Esther is psychically incapacitated, unable even to attach meanings to words (915). This fact, combined with the death of Lady Dedlock before Esther is able to reach her, makes the insight she gains into her identity a dead end, barring her from the female storyline. The woman who could have been for Esther a genuine fairy godmother is dead.

Esther cannot be entirely prevented from claiming her right to tell her own story, however. As a female narrator, she is a de facto participant in the female fairy tale telling tradition, and her narrative often betrays the difficulty Dickens had in negotiating the ideologically incompatible worlds of male and female authorship. Esther's narrative often erupts, like Jane Eyre's madwoman in the attic, in rebellious murmurings. For instance, after she expresses so much faith in Mr. Jarndyce's ability to judge the kind of information it is proper for her to know, Esther protests to herself that the interview has left her feeling "quite easy with him, quite unreserved, quite content to know no more, quite happy" (123). This compulsive repetition has an unconvinced anxiety to it that makes apparent to the reader an underlying longing that only repeated attempts could 
write out of the sentence. Because of her position within a male narrative, Esther apparently has more to say than she is authorized to articulate.

While dwelling obsessively is one rhetorical strategy through which the female narrative obtrudes into Dickens's, Esther's refusal to acknowledge or see her own desires is another common occurrence. The effect of this refusal is to deflect the narrative from these desires, leaving gaps or gasps that thrust the reader's attention more fully upon the denied thing. This act of pretended omission gives her rhetorical power to momentarily circumvent her Bluebeards, to peek behind the door without getting blood on the key. ${ }^{22}$ Cicero calls this rhetorical device "praeteritio," but it is often translated as "paralipsis." Of it he says,

Paralipsis occurs when we say that we are passing by, or do not know, or refuse to say that which precisely now we are saying... . This figure is useful if employed in a matter which it is not pertinent to call specifically to the attention of others, because there is advantage in making only an indirect reference to it. ... As a result, it is of greater advantage to create a suspicion by Paralipsis than to insist directly on a statement that is refutable. (Pseudo-Cicero 321)

One example of Esther's use of paralipsis centers on Mr. Woodcourt: "I have omitted to mention in its place, that there was some one else at the family dinner party. It was not a lady. It was a gentleman. It was . . . a young surgeon. He was rather reserved, but I thought him very sensible and agreeable. At least, Ada asked me if I did not, and I said yes" (BH 214). By displacing this mention from its proper chronological place and burying her intended meaning in negatives, Esther ostensibly attempts to hide it. This

\footnotetext{
22 Iterations of this argument have been made by several scholars. Audrey Jaffe uses a Freudian version of paralipsis, called denegation, to explain the advantage this narratological maneuver gives Esther:

"“[D]enegations' derive from judgments about what the ego wishes to take into itself and what it wishes to reject. ... Esther's denegations signal her otherness to herself - the presence of material she wishes to distance herself from. ... Presenting herself as alienated from her own knowledge, Esther cannot be held responsible for what she knows or says" (qtd. in Sternlieb 76). Lisa Sternlieb makes a subtle adjustment to this argument by suggesting that Esther's is a "conscious and retrospective strategy, one that acknowledges without articulating desire" (76).
} 
narrative disruption, however, calls more attention to the ostensibly denied or misplaced thing, allowing Esther to suggest to the reader exactly what she feels. This act is at once liberating and punishing: it gives her a power of expression but is simultaneously selfmarginalizing. But in the architectonics of a story in which acting on one's desires merits severe punishment, this circumlocution is a form of self-protection that allows others to guess what she feels without her having to examine it too closely herself.

Esther is, nevertheless, punished for her narrative audacity in a way that parallels Perrault's punishing of the subversive, potentially feminist moral of his Bluebeard tale with an authoritative, directly stated patriarchal moral. When she encounters Lady Dedlock near Chesney Wold and sees something in her face "that I had pined for and dreamed of when I was a little child" (578), Esther relates, "I looked at her; but I could not see her, I could not hear her, I could not draw my breath. The beating of my heart was so violent and wild, that I felt as if my life were breaking from me" (579). Knowing he cannot keep Esther from talking in her elliptical way, Dickens creates eclipses in her actual sight, making it more difficult for her to express her desires because she can never see the objects of them clearly. This description of the happy revelation of her parentage and fulfillment of one of her deepest desires tallies closely with how she looks at but does not see her desires for Mr. Woodcourt in the earlier quotation. In fact, when she is first approached by Lady Dedlock in the wood, Esther has uncommon trouble discerning who her visitor is: "The perspective was so long, and so darkened by leaves, and the shadows of the branches on the ground made it so much more intricate to the eye, that at first I could not discern what figure it was...she was almost within speaking distance before I knew her" (578). Blindness, then, is a fitting punishment for the one moment in the novel when Esther seems to have some clear insight into her dual position and to be able to say, for once, exactly what she means. As she heads to the brickmaker's cottage to see the 
feverish Jo, she muses, "I had for a moment an undefinable impression of myself as being something different from what I then was. I know it was then, and there, that I had it" (489). Ironically, her certainty is rewarded by the loss of her sight (504).

Like Lewis Carroll, who "at least partially accepts that he can no longer hold out against the possibility of Alice's passage into adulthood" (Knoepflmacher xii) in Through the Looking Glass, Dickens is finally forced to allow Esther to leave her "father's" household, to grow up and enter maturity through marriage to man who equals her in age, love, and sexual viability. Dickens cannot help, however, including a shadow of the infantilized Esther he fantasized about in the form of Caddy Jellyby's baby. This Esther, sickly when she was born, has begun to grow, "but she is deaf and dumb" ( $B H$ 987). The developmental stunting of this projection of Esther Summerson's psyche, who might as well be blind, too, registers Dickens's continued "ambivalence about adult female power" (Knoepflmacher xii).

In fact, this phantom Esther prefigures Dickens's solution to his narrative bind. Dickens never again attempted to use a female narrator in his novels. However, two female narrators appear in a series of stories he published in 1868 in an American magazine, Our Young Folks, and in his own All the Year Round (Zipes 89). Of these four stories, which were given the collective name of Holiday Romance (89), "The Magic Fishbone" purported to have been penned by one Alice Rainbird, aged seven ("Magic Fishbone" 91), and a second tale was written by a younger girl.23 This story is far from

23 "The Perfect Country," written by Miss Nettie Ashford, aged half-past-six, describes a country in which adult and child roles are reversed. In the tale, the children throw the adults a party and discuss how exhausting it is to keep them entertained. She ends by sending her "helpless" parents to a sort of boarding school for adults so that she will no longer be troubled with taking care of them. The other two stories, written by Robin Redfort (self-styled Lieutenant-Colonel) aged nine and William Tinkling (self-styled Esq.) aged eight, deal with more heroic themes. These four tales have been variously collected. See, for instance, Captain Boldheart and Other Stories in A Holiday Romance by Charles Dickens (New York: Macmillan, 1927). 
demonstrating the narratological problems from which Bleak House suffered. In fact, it complacently founds itself on the most conventional expectations about gender roles: "There was once a King," it begins, "and he had a Queen, and he was the manliest of his sex, and she was the loveliest of hers" (91). The heroine of the story, a princess named Alicia, is the oldest of nineteen children ranging in age "from seven years to seven months" (91), and the seven-year-old princess "took care of them all" (92). One day on his way to the Office, the King is stopped by the Good Fairy Grandmarina, who tells him to invite Princess Alicia to eat some of the salmon he was then purchasing for dinner, and that after she had eaten, to tell her to polish the fishbone that remained on her plate, which will bring her, only once, "whatever she wishes for, PROVIDED SHE WISHES FOR IT AT THE RIGHT TIME” (92). The king delivers his message, Alicia follows the instructions, and the next day she is provided with an opportunity to use her one wish when her mother falls ill. However, Alicia delays using her wish, despite her father's silent and persistent entreaties, until she knows the King has "done his very very best" (97) to provide for his family. Meanwhile, Alicia has been capably nursing her mother, entertaining and feeding the children, and being about as matronly and responsible as woman of seventy could be expected to be, much less a girl of seven. Alice Rainbird's narrative, in other words, casually performs Dickens's own fantasies about womanhood. Princess Alicia is capable in all the domestic arts and happily works to provide for her father's and the rest of the family's comfort. She possesses a sort of prelapsarian wisdom that allows her to perform all of these duties while remaining a child, unlike Charley, Esther's maid, whose similar experience has given her "an air of age and steadiness that sat so strangely on the childish figure" ( $B H$ 246). Unlike the "elliptical, subversive, openended" fairy tales written by women (Auerbach and Knoepflmacher 8), this one remains untroubled and straightforward in style. Dickens seems to have hit on a way to control the 
expression of a female narrator: to keep her a child. The childish authorship of the story is a shared joke between Dickens and the reader, humorous because of how conscious we are of suspending our disbelief to agree that Alice is the actual author. The childish elements, like Alice's naïveté in believing that nineteen children could be born in the course of seven years, are meant to make the reader fondly dismiss Alice as a serious narrator and collude with Dickens. The story itself becomes a novelty, a stunt that undermines her status as speaker and makes her an obvious mouthpiece for Dickens himself, through which he can freely project and fantasize.

“The Magic Fishbone," written two years before Dickens's own death, probably represents his last policing of female voices. But while he seems to gain control of his puppets in this final attempt, his loss of control in Bleak House proves that women must - and will - grow up. Female expression, so painstakingly controlled in his novel, is not, in the end, effectively silenced. Esther, even as she chokes on the articulation of her own hopes, approaches, via curiosity, the realm of her personal possibilities: "I know that my dearest little pets are very pretty, and that my darling is very beautiful, and that my husband is very handsome ... and that they can very well do without much beauty in me-even supposing - " (989). The dash, the penultimate typographic marker in the text, offers a perpetual threat of rupture to the hopeful period Dickens has placed there. For Esther's last moment of strategic evasion, Warner writes a fitting epitaph: "Women's capacity for love and action tragically exceeded the permitted boundaries of their lives" (393). Nevertheless, even in the bleakest of houses, storytelling has helped women survive-and thrive. 


\section{Bibliography}

Auerbach, Nina and U. C. Knoepflmacher. Introduction. Forbidden Journeys: Fairy Tales and Fantasies by Victorian Women Writers. Chicago: University of Chicago Press, 1992. 1-10.

Barzilai, Shuli. "The Bluebeard Barometer: Charles Dickens and Captain Murderer." Victorian Literature and Culture 32 (2004): 505-524.

--. "Charles Dickens and Captain Murderer." Tales of Bluebeard and His Wives from Late Antiquity to Postmodern Times. New York: Routledge, 2009. 22-42.

Brontë, Charlotte. Jane Eyre. 1847. Toronto: Broadview, 1999.

Carter, Angela. "The Bloody Chamber." The Bloody Chamber. 1979. New York: Penguin, 1993. 7-41.

“curiosity 5a." The Oxford English Dictionary. $2^{\text {nd }}$ ed. 1989. OED Online. Oxford University Press. 28 March $2011<$ http://dictionary.oed.com>.

“curiosity 5b." The Oxford English Dictionary. $2^{\text {nd }}$ ed. 1989. OED Online. Oxford University Press. 28 March $2011<$ http://dictionary.oed.com>.

Dickens, Charles. Bleak House. 1853. London: Penguin, 2003.

--. Captain Boldheart and Other Stories in A Holiday Romance by Charles Dickens. New York: Macmillan, 1927.

--. "Frauds on the Fairies." Fantastic Literature: A Critical Reader. Ed. David Sandner. Westport, CT: Greenwood Publishing, 2004. 56-58.

--. "The Magic Fishbone." Victorian Fairy Tales: The Revolt of the Fairies and Elves. Ed. Jack Zipes. New York: Methuen, 1987. 91-90.

--. "Where We Stopped Growing." The Centenary Edition of the Works of Charles Dickens in 36 Volumes. Ed. B. W. Matz. Vol. 1. London: Chapman \& Hall, 1911.

Eigner, Edwin M. The Dickens Pantomime. Berkeley: University of California Press, 1989.

--. Review of Dickens and the Invisible World: Fairy Tales, Fantasy, and Novel-Making, by Harry Stone. The Yearbook of English Studies 1982: 317-318.

Estés, Clarissa Pinkola. Women Who Run With the Wolves: Myths and Stories of the Wild Woman Archetype. New York: Ballantine Books, 1995.

Gilbert, Susan M. "Jane Eyre and the Secrets of Furious Lovemaking." NOVEL: A Forum on Fiction 31 (1998): 351-372.

Knoepflmacher, U.C. Ventures Into Childland: Victorians, Fairy Tales, and Femininity. Chicago: University of Chicago Press, 1998. 
Kotzin, Michael. Dickens and the Fairy Tale. Bowling Green: Bowling Green University Popular Press, 1972.

Nemesvari, Richard. Introduction. Jane Eyre. By Charlotte Bronte. Toronto: Broadview, 1999.

Newsom, Robert. Dickens on the Romantic Side of Familiar Things: Bleak House and the Novel Tradition. New York: Columbia University Press, 1977.

Perrault, Charles. Histories, or tales of past times. London, 1729. Eighteenth Century Collections Online. Gale. University of Texas at Austin. 8 Dec. 2010 $<$ http://find.galegroup.com.ezproxy.lib.utexas.edu/ecco/infomark.do?\&contentSet $=$ ECCOArticles $\&$ type $=$ multipage $\&$ tabID $=$ T001 $\&$ prodId $=$ ECCO\&docId $=C W 112$ $745620 \&$ source $=$ gale $\&$ userGroupName $=$ txshracd $2598 \&$ version $=1.0 \&$ docLevel $=$ FASCIMILE $>$.

--. "The History of Griselda." Trans. Christopher Betts. The Complete Fairy Tales. Oxford: Oxford University Press, 2009. 9-41.

Preface. Dame Durden: Little Woman from the Bleak House of Charles Dickens. By Charles Dickens. New York: John R. Anderson, 1878.

Pseudo-Cicero. Rhetorica Ad Herennium. Trans. Harry Caplan. Cambridge, MA: Harvard University Press, 1954.

Schor, Hilary M. "Bleak House and the Dead Mother's Property." Dickens and the Daughter of the House. Cambridge: Cambridge University Press, 1999. 101-123.

Sternlieb, Lisa Ruth. The Female Narrator in the British Novel: Hidden Agendas. New York: Palgrave, 2002.

Stone, Harry. Dickens and the Invisible World: Fairy Tales, Fantasy, and Novel-Making. Bloomington: Indiana University Press, 1979.

Tatar, Maria. Introduction. The Classic Fairy Tales. Ed. Maria Tatar. New York: W. W. Norton \& Co., 1999. ix-Xviii.

--. "Introduction: Bluebeard." The Classic Fairy Tales. Ed. Maria Tatar. New York: Norton \& Co., 1999. 138-144.

--. "Introduction: Cinderella." The Classic Fairy Tales. Ed. Maria Tatar. New York: Norton \& Co., 1999. 101-137.

--. Off with Their Heads!: Fairytales and the Culture of Childhood. Princeton: Princeton University Press, 1992.

Warner, Marina. From the Beast to the Blonde: On Fairy Tales and Their Tellers. New York: Noonday Press, 1996.

Wilt, Judith. "Confusion and Consciousness in Dickens's Esther." Nineteenth-Century Fiction 32 (1977): 285-309. 
Winslow, Joan D. "Esther Summerson: The Betrayal of the Imagination." The Journal of Narrative Technique 6 (1976): 1-13.

Zipes, Jack, ed. Victorian Fairy Tales: The Revolt of the Fairies and Elves. New York: Methuen, 1987.

Zwerdling, Alex. "Esther Summerson Rehabilitated.” PMLA 88 (1973): 429-439. 


\section{Vita}

Melissa Smith attended Derby High School, Derby, Kansas. In 2005 she entered the University of Rochester, Rochester, New York, graduating summa cum laude in 2009. She began graduate school at the University of Texas at Austin the same year. She is the author of an article, “At Home and Abroad: Éowyn's Two-fold Figuring as War Bride in The Lord of the Rings," which was published in Mythlore in 2007.

Email address: melissa.smith@rochester.edu

This report was typed by the author. 